\title{
Review of the herpetofauna of Attica, mainland Greece
}

\author{
Ioannis Annousis ${ }^{1}$, Grigoris Kapsalas ${ }^{1}$, Panayiotis Pafilis ${ }^{1}$ \\ 1 Section of Zoology - Marine Biology, Department of Biology, National \& Kapodistrian University of Athens, Panepistimiopolis 15701 Athens, Greece \\ http://zoobank.org/238A22D3-62AC-464D-A282-13A4A052851F \\ Corresponding author: Panayiotis Pafilis (ppafil@biol.uoa.gr)
}

Academic editor: Silke Schweiger • Received 11 November 2020 • Accepted 28 December 2020 • Published 11 January 2021

\begin{abstract}
Although the insular distribution of the rich herpetofauna of Greece has been studied more extensively, the mainland one is still underexplored. The region of Attica in central Greece represents one of these "black spots" in the mainland. Thus, in 2019 we surveyed for the first time the herpetofauna of Attica in a systematic way. We collected 794 field records of 31 species (4 amphibians, 27 reptiles); Testudo graeca and Trachemys elegans were documented for the first time for Attica.
\end{abstract}

\section{Key Words}

amphibians, Greece, reptiles

\section{Introduction}

Greece hosts one of the richest (and locally well-studied) herpetofaunas in Europe, including 76 reptiles (12 endemic) and 25 amphibians (three endemic) (Valakos et al. 2008; Lymberakis et al. 2018). Starting with the French Morea Scientific Expedition (Expédition Scientifique de Morée 1828-1833), numerous naturalists were attracted by the herpetological wealth of Greece and realized extensive field work during the $19^{\text {th }}$ century, describing several new species (Pafilis 2010). This trend has continued with an increasing number of herpetologists visiting Greece (Broggi 2019; Donihue et al. 2020). However, herpetologists, whether they were foreigners or (later) Greeks, had a clear preference to the "showcase" of the Greek herpetofauna - the islands (Christopoulos et al. 2019). As such, the mainland herpetofauna still remains understudied and broad areas have never been surveyed (Pafilis and Maragou 2013).

Attica, the historic region and geographic area where the cities of Athens and Piraeus are located, is no exception. Being a small peninsula at the southern-east part of central Greece (Fig. 1), for decades it served rather as a jetty to herpetologists who set off to visit the thou- sand Aegean islands that harbor some endemic taxa. As a result, although even some of the smallest islets have been surveyed (Pafilis et al. 2016, 2020), our knowledge about the herpetofauna of the mainland part of Attica is very poor. Even though the insular parts of Attica are well-studied (Clark 1967, 1970, 1989, 1997; Broggi 2016), the main body of the peninsula remains largely understudied, following the fate of mainland Greece herpetofauna contrary to the islands (Pafilis and Maragou 2013). The founding fathers of Greek herpetology made brief stops to Attica, reflected in rather laconic reports on the herpetofauna (Bedriaga 1883; Boettger 1888; Werner 1930, 1938; Cyrén 1941; Stepanek 1944). An important source comes from the botanist Theodor von Heldreich who wrote the first Fauna of Greece (1878). The chapters on reptiles and amphibians therein, present valuable information for Attica. The rest of our knowledge is based on checklists that typically reiterate previous findings (Ondrias 1968; Chondropoulos 1986, 1989; Valakos et al. 2008). According to this literature, Attica hosts 27 reptiles (10 lizards, 13 snakes and 4 turtles) and 4 amphibians. Here, we report the results of the first thorough and systematic herpetological survey of Attica aiming at identifying the current species composition and distribution. 


\section{Methods}

\section{Study area}

Hosting two of the main metropolitan centers of Greece (Athens and Piraeus), Attica is the most urbanized area in the country with close to 4 million inhabitants, representing over a third of the nation's population (ELSTAT 2011). Consequently, there are strong ecological pressures on the environment, the natural resources and wildlife, and many regions within Attica are of low environmental quality because of pollution, intense anthropogenic use and habitat fragmentation (Aperghis and Gaethlich 2006). However, Attica spans from $0 \mathrm{~m}$ a.s.l. to $1,413 \mathrm{~m}$ at Parnitha Mt. and still harbors impressive habitat diversity (Fig. 2), including wetlands, lowland croplands with olive groves and vineyards being the dominant type of cultivation for the past 5,000 years (Kouli 2012).

Land use in Attica comprises three major categories (Level 1; Corine Land Cover 2018). The terrestrial part of Attica covers 2,923.2 km². Artificial surfaces (ca. 26.0\% of area) include the basic urban infrastructure, industrial, commercial and transport activities and is generally where most anthropogenic activities take place. Agricultural areas cover approximately $26.7 \%$. Forested and semi-natural areas comprise $46.8 \%$. This is a result of the numerous mountainous reliefs surrounding the major urban areas. Finally, a rather small percentage $(0.8 \%)$ is covered by water, including inland and coastal wetlands, as well as other parts of the coast. Furthermore, the terrestrial part of Attica $\left(2,923.2 \mathrm{~km}^{2}\right)$ comprises nine protected areas belonging to the Natura 2000 ecological network $\left(446.96 \mathrm{~km}^{2}\right.$ or $15.3 \%$ of Attica) and one National Park (14.40 $\mathrm{km}^{2}$ or $\left.0.5 \%\right)$.

The climate is typically Mediterranean, with distinct, long and dry summers and short and wet winters. The highest temperature was recorded in July $\left(46^{\circ} \mathrm{C}\right)$ and the lowest in January $\left(-8{ }^{\circ} \mathrm{C}\right)$, with an average annual temperature of $18.3{ }^{\circ} \mathrm{C}$; rainfall is rather restricted $(400$ $450 \mathrm{~mm}$ ) (Gialamas 2013).

\section{Data collection}

Field work took place from mid-March to mid-August 2019 , throughout the day (8-10+ hours of active field work, depending on the season) whenever weather conditions were seemingly optimal for surveying as many species as possible (clear sky, air temperature less than $37^{\circ} \mathrm{C}$, wind less than five on the Beaufort scale). Atti-

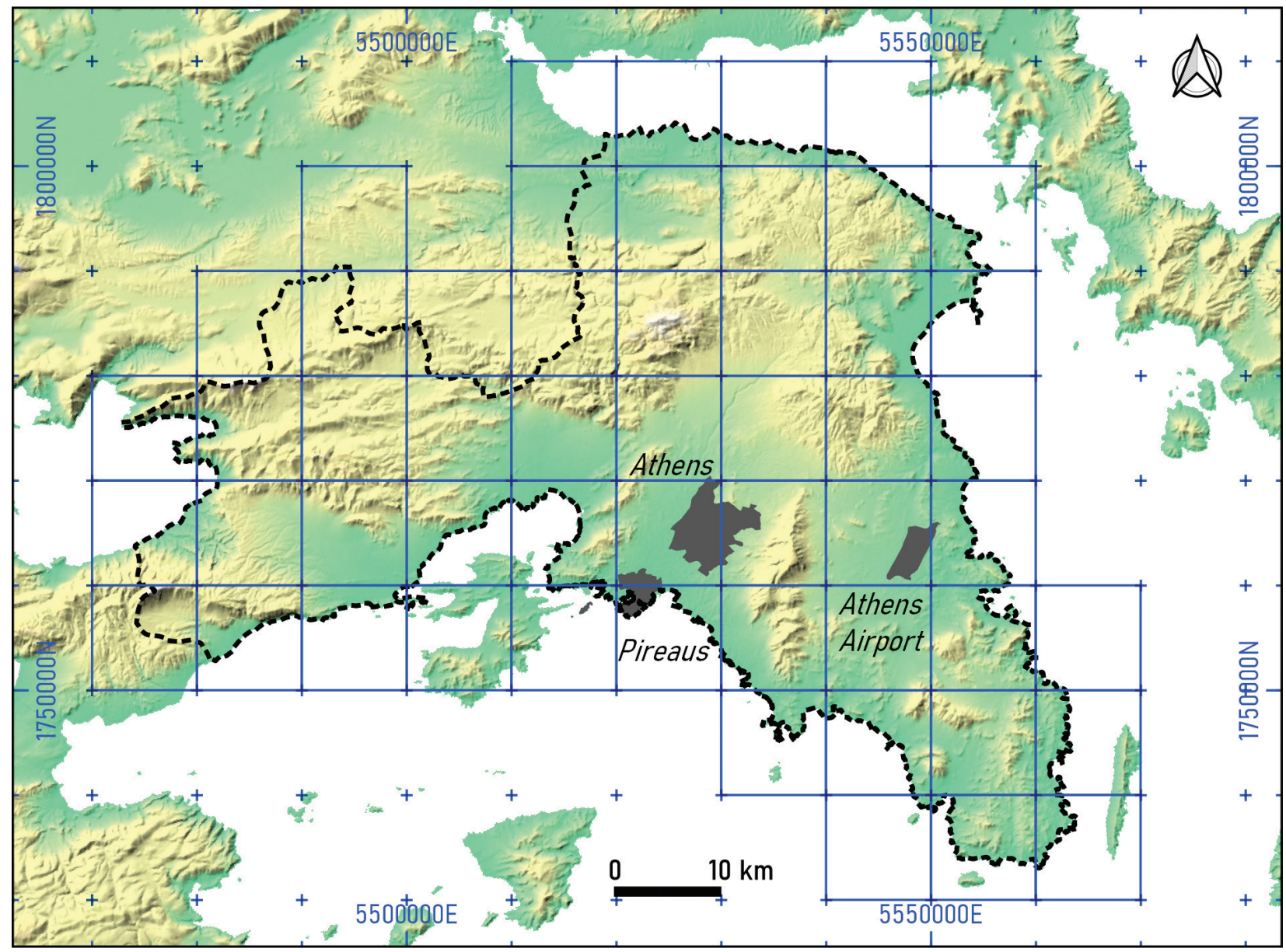

Figure 1. Map of the Attica peninsula at the east part of the central mainland Greece. The terrestrial part of Attica prefecture (dotted line, study site) was divided into a grid of 53 squared cells $(10 \times 10 \mathrm{~km})$ according to the European Reference Grid. 


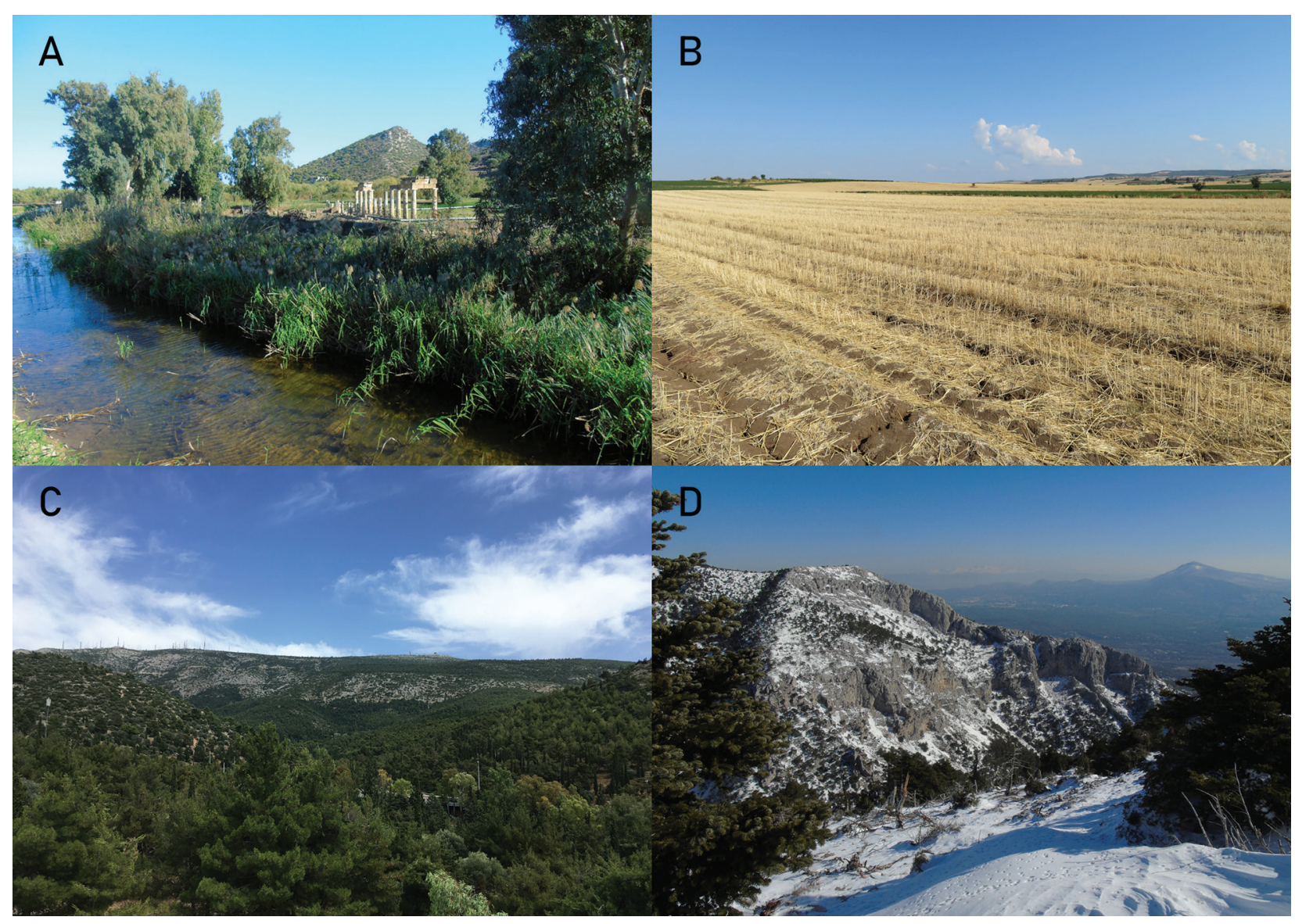

Figure 2. Different habitat types in Attica: A. The small river Erasinos by the ancient Artemis Temple at Vravrona (east Attica); B. Barley cultivations at Erythres plain (west Attica); C. Hymettus Mt. foothills, just next to Athens metropolitan area (central Attica); D. Winter landscape from Parnitha Mt. with Penteli Mt. in the far distance (north Attica).

ca falls into 53 (14 complete and 39 partial) squares of the $10 \times 10 \mathrm{~km}$ European Reference Grid (Suppl. material 1: Fig. S1). Field work was arranged so as to have at least two sampling days in each sampling square, one during the spring and one in the summer. Six squares were excluded from sampling either because of previous wildfires or heavy urban development. In total, 158 sites were sampled (avg. 3 sites per square) within 92 days of field work.

At every site we (three people at least) visually surveyed for conspicuous species (e.g. lacertid lizards, turtles). We employed the line transect method and recorded and identified all reptiles and amphibians found on both sides ( $2 \mathrm{~m}$ ) of the pathway (Lovich et al. 2012; McDiarmid et al. 2012). In each site we walked at least 6 tracks of $200 \mathrm{~m}$ (fixed distance measured with GPS). Furthermore, we devoted a considerable amount of time (1-2 hours, depending on the site characteristics) to overturn rocks, logs and debris and to search in vegetation for more cryptic species such as snakes, legless lizards and toads. Additionally, we visited most known sites that contained aquatic habitats (e.g. rivulets, ponds, lakes, marshes) and which are not that common in Attica. We visually surveyed the water surface and swept underwater with a dip net (net opening: $0.3 \mathrm{~cm}$, pole length: $2.3 \mathrm{~m}$ ) for 30 minutes (Heyer et al. 1994). Finally, we recorded all roadkill and shed snake skin encountered that we could identify to the species level. A hand-held GPS device was used to record the exact coordinates of each observation. Species taxonomy follows Uetz et al. (2020).

To assess the diversity of amphibians and reptiles in Attica, we calculated species richness, Shannon's diversity index $\left(\mathrm{H}^{\prime}\right)$ and Pielou's evenness index $\left(\mathrm{J}^{\prime}\right)$. Species richness refers to the total number of species recorded per grid cell. Shannon diversity index $\left(\mathrm{H}^{\prime}\right)$ was calculated as:

$$
\mathrm{H}^{\prime}=-\Sigma\left(\mathrm{p}_{i} \cdot \ln \left(\mathrm{p}_{i}\right)\right)
$$

where $p_{i}$ is defined as the proportion of the locations of species " $i$ " to the total number of locations for all species. The evenness was represented by Pielou's evenness index:

$$
\mathrm{J}^{\prime}=\mathrm{H}^{\prime} / \mathrm{H}_{\max },
$$

where $\mathrm{H}^{\prime}$ is the number derived from the Shannon diversity index and $\mathrm{H}_{\text {max }}$ is the maximum possible value of $\mathrm{H}^{\prime}$ (if every species was equally likely).

Diversity indices were calculated in R 3.6.2 (R Core Team 2019) using the "vegan" package (Oksanen et al. 2019). 


\section{Results}

We recorded 31 species based on 794 observations (Table 1). Amphibians were represented by 4 species that were concentrated mainly in the north (Fig. 3). We encountered 8 species of lizards, 13 snakes and 6 turtles (Fig. 3). However, only a handful of species were really

Table 1. Amphibians and reptiles in Attica, by family. The first citations from Attica, the number of records and the equivalent percentages. All species records for Attica were confirmed except for the European green lizard (Lacerta viridis) and the Greek snake skink (Ophiomorus punctatissimus).

\begin{tabular}{|c|c|c|c|}
\hline Family/species & Cited in literature & $\begin{array}{c}\text { Number } \\
\text { of records }\end{array}$ & $\begin{array}{c}\text { Percentage } \\
\text { of records }\end{array}$ \\
\hline \multicolumn{2}{|l|}{ Amphibia } & 189 & $100 \%$ \\
\hline \multicolumn{4}{|l|}{ Bufonidae } \\
\hline Bufo bufo & von Heldreich 1878 & 14 & $7.4 \%$ \\
\hline Bufotes viridis & von Heldreich 1878 & 18 & $9.52 \%$ \\
\hline \multicolumn{4}{|l|}{ Hylidae } \\
\hline Hyla arborea & von Heldreich 1878 & 2 & $1.05 \%$ \\
\hline \multicolumn{4}{|l|}{ Ranidae } \\
\hline Pelophylax kurtmuelleri & $\begin{array}{c}\text { von Heldreich } 1878 \text { (as Rana } \\
\text { esculenta) }\end{array}$ & 155 & $82.01 \%$ \\
\hline \multicolumn{2}{|l|}{ Sauria } & 320 & $100 \%$ \\
\hline \multicolumn{4}{|l|}{ Anguidae } \\
\hline Pseudopus apodus & von Heldreich 1878 & 18 & $5.62 \%$ \\
\hline \multicolumn{4}{|l|}{ Gekkonidae } \\
\hline Hemidactylus turcicus & Expéd. Scient. de Morée 1833 & 8 & $2.5 \%$ \\
\hline Mediodactilus kotschyi & Bedriaga 1883 & 10 & $3.12 \%$ \\
\hline \multicolumn{4}{|l|}{ Lacertidae } \\
\hline Lacerta trilineata & Cyrén 1941; Werner 1938 & 138 & $43.12 \%$ \\
\hline Podarcis erhardii & Cyrén 1941; Werner 1938 & 8 & $2.5 \%$ \\
\hline Podarcis muralis & Cyrén 1941; Werner 1938 & 8 & $2.5 \%$ \\
\hline \multicolumn{4}{|l|}{ Scincidae } \\
\hline Ablepharus kitaibelii & Werner 1938, Cyrén 1941 & 32 & $10 \%$ \\
\hline Chalcides ocellatus & $\begin{array}{c}\text { von Heldreich 1878; Werner } \\
\text { 1938; Cyrén 1941 }\end{array}$ & 98 & $30.62 \%$ \\
\hline \multicolumn{2}{|l|}{ Ophidia } & 121 & $100 \%$ \\
\hline \multicolumn{4}{|l|}{ Colubridae } \\
\hline Coronella austriaca & von Heldreich 1878 & 2 & $1.65 \%$ \\
\hline Elaphe quatuorlineata & $\begin{array}{c}\text { von Heldreich } 1878 \text {; Bedriaga } \\
\text { 1883; Boettger } 1888\end{array}$ & 6 & $4.95 \%$ \\
\hline Hierophis gemonensis & Boettger 1888 & 7 & $5.78 \%$ \\
\hline Zamenis situla & $\begin{array}{c}\text { von Heldreich 1878; Boettger } \\
\text { 1888; Werner } 1912\end{array}$ & 3 & $2.48 \%$ \\
\hline Dolichophis caspius & Werner 1938 & 1 & $0.82 \%$ \\
\hline Platyceps najadum & $\begin{array}{l}\text { von Heldreich 1878; Werner } \\
1912,1930\end{array}$ & 8 & $6.61 \%$ \\
\hline Telescopus fallax & Boettger 1888; Werner 1938 & 3 & $2.48 \%$ \\
\hline Malpolon insignitus & Werner 1938; Stepanek 1944 & 32 & $26.44 \%$ \\
\hline \multicolumn{4}{|l|}{ Erycidae } \\
\hline Eryx jaculus & $\begin{array}{l}\text { Boettger 1888; Cyrén 1941; } \\
\text { Werner } 1930\end{array}$ & 1 & $0.82 \%$ \\
\hline \multicolumn{4}{|l|}{ Natricidae } \\
\hline Natrix natrix & $\begin{array}{l}\text { von Heldreich 1878; Boettger } \\
\text { 1888; Werner 1912; Cyrén } \\
1941\end{array}$ & 14 & $11.57 \%$ \\
\hline Natrix tessellate & $\begin{array}{c}\text { von Heldreich 1878; Boettger } \\
\text { 1888; Werner 1938; Cyrén } \\
1941\end{array}$ & 2 & $1.65 \%$ \\
\hline \multicolumn{4}{|l|}{ Viperidae } \\
\hline Vipera ammodytes & Boettger 1888; Werner 1912 & 26 & $21.48 \%$ \\
\hline \multicolumn{4}{|l|}{ Typhlopidae } \\
\hline $\begin{array}{l}\text { Xerotyphlops } \\
\text { vermicularis }\end{array}$ & $\begin{array}{l}\text { Boettger 1888; Werner 1938; } \\
\text { Stepanek } 1944\end{array}$ & 16 & $13.22 \%$ \\
\hline \multicolumn{2}{|l|}{ Turtles } & 164 & $100 \%$ \\
\hline \multicolumn{4}{|l|}{ Emydidae } \\
\hline Emys orbicularis & Expéd. Scient. de Morée 1833 & 1 & $0.06 \%$ \\
\hline Trachemys scripta & & 2 & $1.83 \%$ \\
\hline \multicolumn{4}{|l|}{ Geoemydidae } \\
\hline Mauremys rivulata & Expéd. Scient. de Morée 1833 & 33 & $20.12 \%$ \\
\hline \multicolumn{4}{|l|}{ Testudinidae } \\
\hline Testudo graeca & & 3 & $1.83 \%$ \\
\hline Testudo marginata & Werner 1930 & 118 & $71.95 \%$ \\
\hline Testudo hermanni & Expéd. Scient. de Morée 1833 & 6 & $3.65 \%$ \\
\hline
\end{tabular}

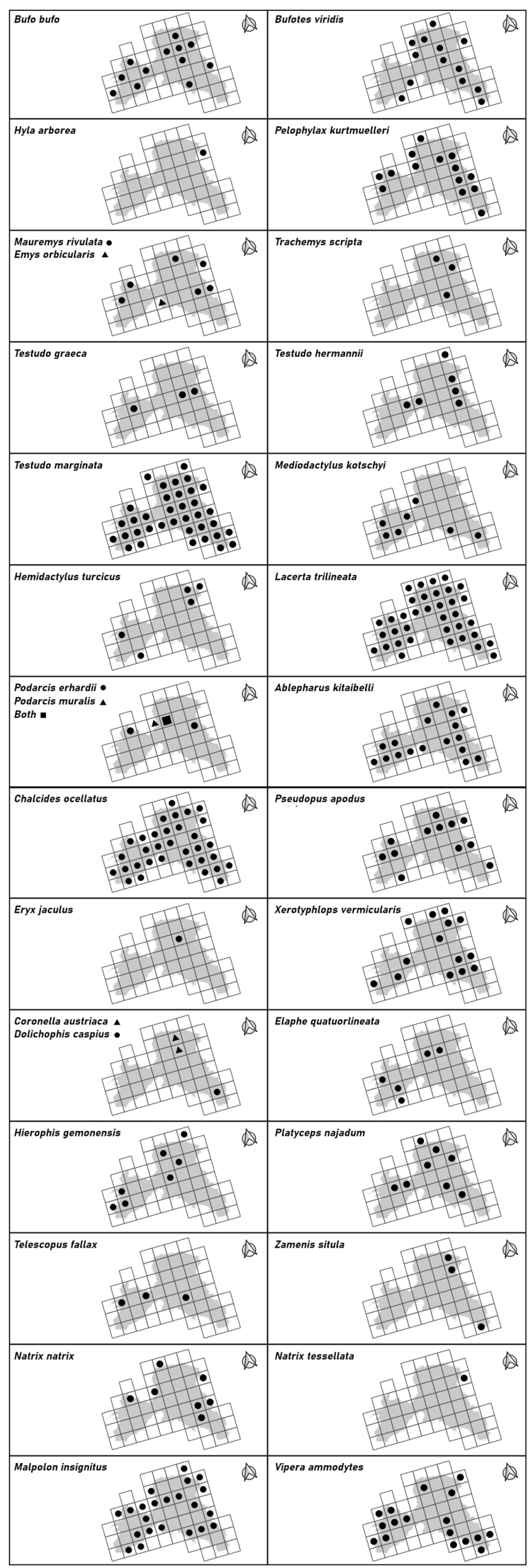

Figure 3. Amphibian and reptilian species distribution in Attica, mainland Greece, superimposed on the $10 \times 10 \mathrm{~km}$ European Reference Grid. Circles, triangles and squares represent occurrence in a cell. 


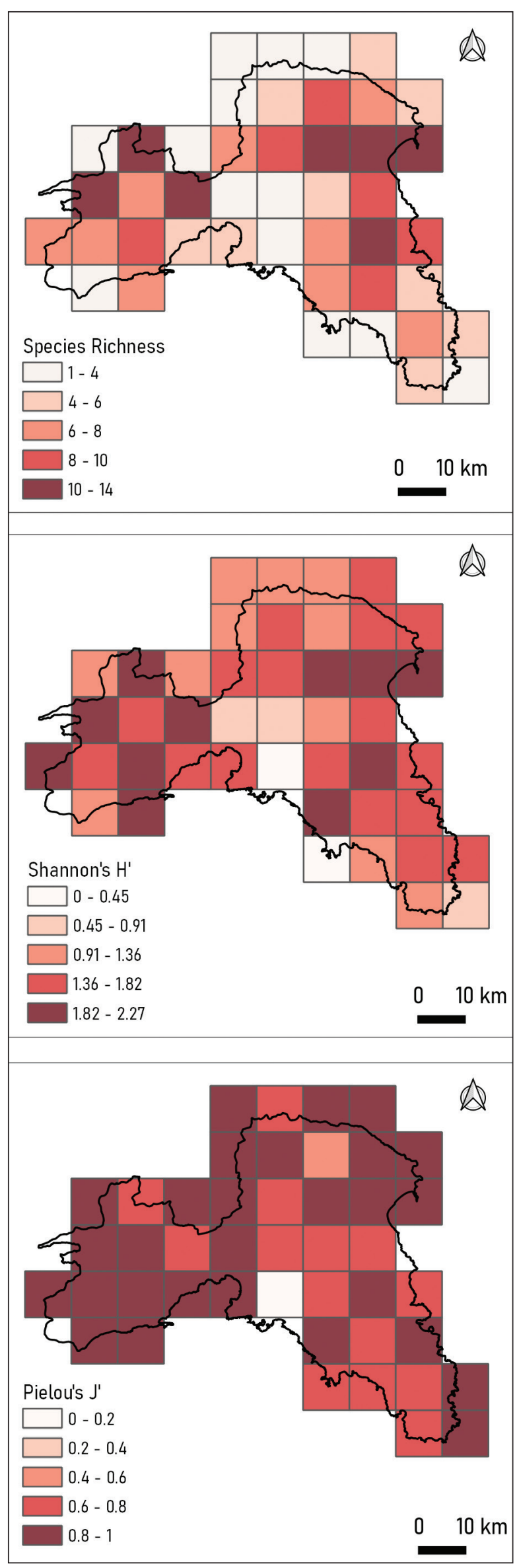

Figure 4. Amphibian and reptilian diversity in Attica: Species richness (top), Shannon's H (middle), Pielou's J' (bottom). abundant (based on the number of observations). Among lizards, the most common species by far were the Balkan green lizard (Lacerta trilineata) and the ocellated skink (Chalcides ocellatus), comprising $73.7 \%$ of all records (Table 1). Among turtles, the marginated tortoise (Testudo marginata) represented $71.95 \%$ of the records of chelonians (Table 1). The more common snakes were the nosehorned viper (Vipera ammodytes) and the eastern Montpellier snake (Malpolon insignitus) (Table 1). Finally, the most frequently observed amphibian was the Balkan frog (Pelophylax kurtmuelleri) with 82.01\% (Table 1).

We verified the presence of all species that have been reported in the literature, except for two: the European green lizard (Lacerta viridis) and the Greek snake skink (Ophiomorus punctatissimus) (Table 1). Also, the presence of the Erhard's wall lizard (Podarcis erhardii), considered almost extinct from Attica (Dimitropoulos and Gaetlich 1986), was recorded in three different sites. Two species that were not mentioned before, the Greek tortoise (Testudo graeca) and the invasive red-eared slider (Trachemys scripta elegans) were detected during fieldwork.

Species richness and Shannon's H' index show that herpetofauna diversity was higher in the less disturbed areas (Fig. 4). We found $22 \%$ of records in Natura sites, $23 \%$ in wetlands, $23 \%$ in mountain areas and $32 \%$ in cultivations. Pielou's evenness index J' on the other hand underlines a uniform pattern of occurrence (Fig. 4). Natura sites hosted the fewest individuals but most species (199 records, 24 species) compared to the rest types of biotopes, highlighting the importance of ex situ preservation.

\section{Discussion}

In this study we assessed for the first time the herpetofauna of Attica in a systematic way. Our findings corroborate the presence of almost all species reported in the past. Of the species we did not detect, O. punctatissimus was only reported by Bedriaga (1883) and further reports (Bischoff 1981, Chondropoulos 1986) refer to Bedriaga's finding. According to recent research on its systematics, O. punctatissimus is limited to the Peloponnese peninsula south of Attica, two islands, and one mainland site (Iraion, Prefecture of Corinth) (Kornilios et al. 2018). It is dubious whether this species ever occurred in Attica. The L. viridis reported from Attica (von Heldreich 1878) has been later identified to be in fact L. trilineata; currently, L. viridis occurs only in northern Greece and does not occur in Attica (Valakos et al. 2008).

Though the species is reported in old checklists from Attica (Ondrias 1968), its current presence was strongly disputed. Apart from a single verified report in Parnitha Mt (Pafilis and Simou 2006), there were only speculations on its presence. We were able to verify the presence of $P$. erhardii in Attica in three locations. In the past, the species used to be common in Attica and von Wettstein (1953) referred to individuals that were collected in the mountains Hymettus, Penteli and Tourkovounia during the early $20^{\text {th }}$ century. However, Cyren (1935) and Werner 
(1938) mentioned that the species was already rare by the time they visited Attica. Dimitropoulos and Gaetlich (1986) reported that many of the Attic populations have been extinct and "the species is likely to soon disappear from the whole of Attica". Thus, we were surprised to spot three $P$. erhardii populations besides that in Parnitha Mt., two at Penteli Mt. (15 km from each other) and one in the Erythres plain at the west of Attica (Fig. 4). It is hard to tell whether our findings reflect recently settled populations or old ones that were re-discovered thanks to systematic field work. The habitat types where the species was found (maquis and phrygana) are very common in Attica, and thus it is possible that new populations may be revealed in the future.

We also recorded for the first time in Attica three individuals of the Greek tortoise (T. graeca), at three places (Fig. 3). This species normally occurs in central and northern Greece and on islands of northeastern Aegean Sea. Nonetheless, we should highlight that this species is widely used as a pet and might have been anthropogenically transported to places outsides its natural range. Whether such, putatively, transferred animals may pave the way for new populations is something to survey in the future. Another chelonian species, the European pond turtle (E. orbicularis) was found in Attica in only one location (Fig. 3). Fresh water bodies, and especially unpolluted ones, are a rare commodity in the area, and thus this species cannot sustain viable populations. However, we cannot rule out the possibility of human transportation, a common practice for many chelonians. Indeed, that was the way the invasive $T$. scripta elegans was introduced in Attica. During our field work, we detected three populations (first record for Attica) in places receiving high human traffic for recreation activities. It is not known yet whether these populations are sustained by people releasing new animals or if the local T. srcipta elegans are able to reproduce as in other countries in south Europe.

Two invasive species that were recently recorded in the Athens metropolitan area, the Italian wall lizard (Podarcis siculus) (Adamopoulou 2015) and the Andalusian wall lizard (Podarcis vaucheri) (Spilani et al. 2018) have seemingly not dispersed much beyond the locations of the original sightings. The same goes for other native species with different origin that were found inside the Athenian urban districts like the common wall gecko (Tarentola mauritanica) (Strachinis and Pafilis 2018), the Peloponnese wall lizard (Podarcis peloponnesiacus) (Hedman et al. 2017) and the Greek Algyroides (Algyroides moreoticus) (Deimezis-Tsikoutas et al. 2020). Apparently, all these species arrived in Athens thanks to humans, but their dispersal so far seems to be limited to urban areas and did not affect the rest of Attica, at least so far.

As mentioned earlier, fresh waters are not common in Attica. This fact explains the limited number of amphibian observations (Fig. 3). In particular, species that need high air humidity and permanent water bodies, like the European tree frog (Hyla arborea), seem to be very rare in Attica. Snakes on the other hand were ubiquitous and with the highest diversity among all sampled groups (Fig. 3). Attica's environmental and ecological conditions support both high snake diversity and abundance and this is obvious by their large numbers. In addition, people living in Attica have more positive behaviors when encountering snakes compared to those inhabiting provincial Greece where killing snakes on sight is the rule.

According to our results, diversity was higher in areas that were seemingly less impacted by human activities (Fig. 4). The species richness and Shannon's H' index follow a similar pattern, with most species concentrated on or around the relatively undisturbed mountainous masses of Attica. Pielou's evenness index J' shows a rather uniform pattern with relatively high values. This may imply communities without strongly dominant species, where in both rich and poor communities, the abundances of individual species are not highly different.

More herpetological surveys on Attica will shed light on the occurrence of cryptic species, such as $O$. punctatissimus, the presence of which cannot be ruled out with certainty. Also, future surveys are urgently required to monitor potential further dispersal of the alien species that recently invaded Athens metropolitan area and may expand to the rest of Attica with important effects on the local herpetofauna.

\section{Acknowledgements}

We thank Apostolos Christopoulos, Antonis Antonopoulos, Thanos Georgakopoulos and Elpida Hamzin for their assistance in the field during this study. We thank a reviewer for extended comments that greatly improved the initial manuscript. Field work was done under the permit 7M7T4653П8ПА5 issued by the Ministry of the Environment.

\section{References}

Adamopoulou C (2015) First record of Podarcis siculus (Rafinesque-Schmaltz, 1810) from Greece. Herpetozoa 27: 187-188.

Aperghis GG, Gaethlich M(2006) The natural environment of Greece: An invaluable asset being destroyed. Southeast European and Black Sea Studies 6: 377-390. https://doi.org/10.1080/14683850600861986

Bedriaga J (1883) Die Amphibien und Reptilien Griechenlands. Zoologischer Anzeiger 6: 216-220.

Bischoff W (1981) Ophiomorus punctatissimus (Bibron and Bory 1833) - Schlangenskink. In: Böhme IW (Ed.) Handbucj der Reptilien und Amphibien Europas. Bans 1. Echsen (Sauria). Akademie der Verlagsges. Wiesbaden, 366-372 pp.

Boettger O (1888) Verzeichniss der von Hrn. E. von Oertzen aus Griechenland und aus Kleinasien mitgebrachten Batrachier und Reptilien. Verlag der Koeniglichen Akademie der Wissenschaften. Berlin 1: 139-186.

Broggi M (2016) The herpetofauna of the Ilsand of Kythera (Attica, Greece) (Amphibia; Reptilia). Herpetozoa 29: 37-46.

Broggi M (2019) Herpetological notes on Mauremys, Pelophylax and Stellagama from the Cyclades island of Tinos (Greece). Herpetozoa 31: 225-229. 
Chondropoulos BP (1986) A checklist of the Greek reptiles. I. The lizards. Amphibia-Reptilia 7(3): 217-235. https://oi. org/10.1163/156853886X00028

Chondropoulos BP (1989) A checklist of the Greek reptiles. II. The snakes. Herpetozoa 2(1/2): 3-36.

Christopoulos A, Verikokakis AG, Detsis V, Nikolaidis I, Tsiokos L, Pafilis P, Kapsalas G (2019) First records of Eryx jaculus (Linnaeus, 1758) from Euboea Island. Greece (Squamata: Boidae). Herpetology Notes 12: 663-666.

Clark R (1967) Herpetofauna of the islands of the Argo-Saronic Gulf. Greece. Proccedings of the California Academy of Science 35(2): 23-36.

Clark RJ (1970) A further contribution to the herpetofauna of the islands of the Argo-Saronic Gulf. Greece. British Journal of Herpetology 4: $185-188$.

Clark R (1989) A check list of the herpetofauna of the Argo-Saronic Gulf district. Greece. British Herpetological Society bulletin 28: 8-24.

Clark R (1997) The herpetofauna of the uninhabited islands of the Spetsai/Hydra island complex. Greece. British Herpetological Society bulletin 58: 36-43.

Cyrén O (1935) Herpetologisches vom Balkan. Blätter für Aquarienund Terrariener-Kunde. Stuttgart 46: 129-135.

Cyrén O (1941) Beiträge zur Herpetologie der Balkanhalbinsel. Mitt. Kgl. Naturw. Inst. Sofia 14: 36-152.

Deimezis-Tsikoutas A, Kapsalas G, Antonopoulos A, Strachinis I, Pafilis P (2020) Algyroides nigropunctatus (Squamata: Lacertidae) in the city of Athens: An unexpected finding. Russian Journal of Herpetology 27(3): 172-174. https://doi.org/10.30906/1026-2296-2020-27-3-172-174

Dimitropoulos A, Gaetlich M (1986) The Reptiles of Athens. Herptile 11: $62-65$

Donihue CD, Herrel A, Martín J, Foufopoulos J, Pafilis P, Baeckens S (2020) Chemical signal evolution is rapid and repeatable: lizards evolve more complex chemical fingerprints on experimental islets. Journal of Animal Ecology 89: 1458-1467. https://doi. org/10.1111/1365-2656.13205

Expédition scientifique de Morée (1833) Section des sciences physiques, Ministère de l'éducation nationale, France. Commission scientifique de Morée, F.G. Levrault, Paris, Tome III: Première Partie: Zoologie.

Hedman H, Kapsalas G, Karameta E, Psonis N, Poulakakis N, Foufopoulos J, Pafilis P (2017) First record of Podarcis peloponnesiacus (Bibron \& Bory, 1833) from outside the Peloponnese. Herpetozoa 29: 190-193.

Heldreich T (1878) La Faune de Grèce. Imprimerie de Philokalie. Athènes.

Heyer RW, Donnelly MA, McDiarmid RW, Hayek LC, Foster MS [Eds] (1994) Measuring and monitoring biological diversity. Standard methods for Amphibians. Smithsonian Institution Press, Washington DC.

Jaeger R (1994) Transect sampling. In: Measuring and monitoring biological diversity. Smithonian Institution Press, Washington, 103-107.

Kornilios P, Kumlutas Y, Lymberakis P, Ilgaz C (2018) Cryptic diversity and molecular systematics of the Aegean Ophiomorus skinks (Reptilia: Squamata), with the description of a new species. Journal of Zoological Systematics and Evolutionary Research 56: 364-381. https://doi.org/10.1111/jzs.12205

Kouli K (2012) Vegetation development and human activities in Attiki (SE Greece) during the last 5,000 years. Vegetation Historical Archaeobotany 21: 267-278. https://doi.org/10.1007/s00334-011-0336-9
Lovich RE, Hayes WK, Mushinsky H, Rodda GH (2012) Transect surveys, including line distance. In: McDiarmid RW, Foster MS, Guyerm C (Eds) Reptile biodiversity, standard methods for inventory and monitoring. University of California Press, 227-234.

Lymberakis P, Pafilis P, Poulakakis N, Sotiropoulos K, Valakos ED (2018) The Amphibians and Reptiles of the Aegean Sea. In: Sfenthourakis S, Pafilis P, Parmakelis A, Poulakakis N, Triantis KA (Eds) Biogeography and Biodiversity of the Aegean. In honour of Prof. Moysis Mylonas. Broken Hill Publishers Ltd, Nicosia, 169-189.

McDiarmid RW, Foster MS, Guyer C, Gibbons JW, Chernoff N (2012) Reptile Biodiversity: Standard Methods for Inventory and Monitoring. University of California Press, 412 pp. https://oi. org/10.1525/9780520952072

Oksanen J, Blanchet FG, Friendly M, Kindt R, Legendre P, McGlinn D, Minchin PR, O’Hara RB, Simpson GL, Solymos P, Henry H, Stevens M, Szoecs E, Wagner H (2019) vegan: Community Ecology Package. R package version 2.5-6. https://CRAN.R-project.org/package=vegan Ondrias JC (1968) Liste des Amphibiens et des reptiles de la Gréce. Biologia Gallo-Hellenica 2: 111-135.

Pafilis P, Simou C (2006) The southernmost geographic distribution of Podarcis erhardii. Herpetological Review 37(2): 361-362.

Pafilis P (2010) A brief history of Greek herpetology. Bonn Zoological Bulletin 57(2): 329-345.

Pafilis P, Maragou P (2013) One more record of Lacerta viridis (Laurenti, 1768) from Macedonia. Herpetozoa 26: 101-102.

Pafilis P, Lymberakis P, Sagonas K, Valakos ED (2016) The particularities of a remote islet shape the thermoregulatory profile of an endemic Mediterranean lizard. Journal of Thermal Biology 61: 55-60. https://doi.org/10.1016/j.jtherbio.2016.08.007

Pafilis P, Triantis K, Anastasiou I, Proios K, Valakos ED (2020) A Gecko archipelago: a herpetological survey on Lichadonissia, a small islet group in Greece. Herpetology Notes 13: 25-28.

R Core Team (2019) R: A language and environment for statistical computing. R Foundation for Statistical Computing, Vienna. https:// www.R-project.org

Spilani L, Strachinis I, Lampropoulos A, Tsigas P, Poulakakis N, Pafilis P (2018) Podarcis vaucheri (Sauria: Lacertidae) far away from home: a new invasive species in Greece. Amphibia-Reptilia 39: 363-368. https://doi.org/10.1163/15685381-18000002

Stepanek O (1944) Zur Herpetologie Griechenlands. Vestn. ceskosl. zool. Spol 9: 123-147.

Strachinis I, Pafilis P (2018) First record of Tarentola mauritanica (Linnaeus, 1758) from Athens, Greece. Herpetozoa 31: 98-99.

Uetz P, Freed P, Hošek J [Eds] (2020) The Reptile Database. http:// www.reptile-database.org [accessed December 21, 2020]

Valakos ED, Pafilis P, Sotiropoulos K, Lymberakis P, Marangou P, Foufopoulos J (2008) Reptiles and Amphibians of Greece. Chimaira Publications, Frankfurt am Mainz, 463 pp.

Werner F (1912) Beitraege zur Kenntnis der Reptilien und Amphibien Griechenlands. Archive fuer Naturgeschichte 78: 167-180.

Werner F (1930) Contribution to the knowledge of the reptiles and amphibians of Greece, especially the Aegean islands. Occasional papers of the University of Michigan Museum of Zoology 211: 1-47.

Werner F (1938) Die Amphibien und Reptilien Griechenlands. Zoologica $35: 1-11$.

Wettstein O (1953) Herpetologia Aegaea. Sitzungsberichte der Mathematischen-Naturwissenschafftlichen Klasse Abteilung B 162: 651-833. https://doi.org/10.1007/978-3-662-25591-9_1 


\section{Supplementary material 1}

\section{Figure $\mathbf{S 1}$}

Authors: Ioannis Annousis, Grigoris Kapsalas, Panayiotis Pafilis Data type: png image

Explanation note: Grid cell codes following the EEA Grid nomenclature.

Copyright notice: This dataset is made available under the Open Database License (http://opendatacommons.org/licenses/ $\mathrm{odbl} / 1.0 /)$. The Open Database License (ODbL) is a license agreement intended to allow users to freely share, modify, and use this Dataset while maintaining this same freedom for others, provided that the original source and author(s) are credited.

Link: https://doi.org/10.3897/herpetozoa.34.e60668.suppl1

\section{Supplementary material 2}

\section{Table S1}

Authors: Ioannis Annousis, Grigoris Kapsalas, Panayiotis Pafilis Data type: doc. table

Explanation note: The exact location for all records. The number of individuals found per locality. Other findings such as road kill (RK) and snake shirt (SS).

Copyright notice: This dataset is made available under the Open Database License (http://opendatacommons.org/licenses/ $\mathrm{odb} / 1.0 /$ ). The Open Database License (ODbL) is a license agreement intended to allow users to freely share, modify, and use this Dataset while maintaining this same freedom for others, provided that the original source and author(s) are credited. Link: https://doi.org/10.3897/herpetozoa.34.e60668.suppl2 